\title{
Emergence trap for woodpile insects provides two interesting species of Neuropterida from Sardinia
}

\author{
Roberto Rattu', Roberto A. Pantaleoni ${ }^{2,3, *}$ \& Rinaldo Nicoli Aldini ${ }^{4}$ \\ ${ }^{1}$ Via del Pozzetto 1 - 09126 Cagliari, Italy; e-mail: robertorattu@libero.it \\ ${ }^{2}$ Dipartimento di Agraria, sezione di Entomologia, Università degli Studi di Sassari, Via Enrico de Nicola - 07100 \\ Sassari, Italy; e-mail: pantaleo@uniss.it; robertoapantaleoni@gmail.com \\ ${ }^{3}$ Istituto di Ricerca sugli Ecosistemi Terrestri, Consiglio Nazionale delle Ricerche (IRET-CNR), Traversa la Crucca \\ 3, Regione Baldinca - 07100 Li Punti, Sassari, Italy \\ ${ }^{4}$ Dipartimento di Scienze delle Produzioni Vegetali Sostenibili (Di.Pro.Ve.S.), Area 'Protezione sostenibile delle \\ piante e degli alimenti', Facoltà di Scienze Agrarie, Alimentari e Ambientali, Università Cattolica del Sacro Cuore, \\ via Emilia Parmense 84 - 29122 Piacenza, Italy; e-mail: rinaldo.nicoli@unicatt.it \\ ${ }^{*}$ Corresponding author
}

\begin{abstract}
An emergence trap for woodpile insects, assembled in the coppice holm oak forest of San Gregorio (SE-Sardinia), captured few specimens of only two species of Neuropterida, but these were very interesting ones: Isoscelipteron glaserellum (U. Aspöck, H. Aspöck et Hölzel, 1979) (Neuroptera Berothidae), new to Italy, and Dendroleon pantherinus (Fabricius, 1787) (Neuroptera Myrmeleontidae), new to Sardinia. Further specimens of both species were collected at the same site using other methods. An old find of Dendroleon pantherinus, previously considered unreliable, was confirmed. The ecology and rarity of both species are discussed.
\end{abstract}

KEY WORDS Isoscelipteron glaserellum; Berothidae; Dendroleon pantherinus; Myrmeleontidae; geographic distribution.

Received 30.08.2020; accepted 01.12.2020; published online 23.12.2020

\section{INTRODUCTION}

Some insect species are considered rare because they are indeed rare in collections, but often their true rarity is questionable. Years ago, when defining pseudo-rarity, Gaston (1994: cfr. §2.5.2) wrote: "Species may appear to be rare because methods appropriate to determining their true abundances and range sizes have not been applied, have not been applied in the right place, or have not been applied at the right time". Confirming this obvious affirmation, much anecdotal evidence but few published papers (e.g., Duelli et al., 2006) exist for Neuropterida. Species living in the canopy, or having larvae which live concealed together with adults with a very short flying period, are typically apparently rare species. This pseudo-rarity is evident for adults which are not regularly captured using the more frequent sampling methods applied to Neuropterida (beating, sweeping, light-trapping). Methods applied for other insect orders sometimes permit collection of very interesting taxa among Neuropterida; a paradigmatic example is the discovery by Ghilarov (1962) from soil samples of the first Dilaridae larva living in soil.

Thanks to one of the authors (RR), an emergence trap for insects coming out from freshly cut firewood unexpectedly captured two species of Neuropterida new to Sardinia: Isoscelipteron glaserellum (U. Aspöck, H. Aspöck et Hölzel, 1979) 
(Neuroptera Berothidae), and Dendroleon pantherinus (Fabricius, 1787) (Neuroptera Myrmeleontidae). These findings are reported here and integrated with other ecological and distributional data.

\section{MATERIAL AND METHODS}

The emergence trap derives from the prototype device described by Owen $(1989,1992)$ : a device consisting in a pyramidal netting tent positioned on a woodpile. In our case the net was a readily-available bed mosquito net (Fig. 1). The woodpile is totally renewed each year in spring, is formed of freshly cut logs (average diameter $10 \mathrm{~cm}$ ) of (prevailing) holm oak (Quercus ilex L.) and (occasional) strawberry tree (Arbutus unedo L.). The wood logs are consumed regularly during the cold season.

The trap was placed at the hamlet of San Gregorio, in the Sinnai council district, SE-Sardinia, 39॰18'19'N 9'22'10''E. The dominant environment is a coppice holm oak forest. The trap was checked, day and night, at least once a week. It was set up in 2017.

Information about preparation, conservation and deposit collection are provided in the following sections, together with collection data.

\section{RESULTS}

Isoscelipteron glaserellum (U. Aspöck, H. Aspöck et Hölzel, 1979) Neuroptera Berothidae

EXAmined MATERIAL. Specimens from emergence trap. * 22 June 2020, 1 male (Fig. 2) and 1 female, preserved in alcohol, R.A. Pantaleoni collection. * 21 September 2020, 1 female (Fig. 3), collected from the external side of the trap, preserved in alcohol, R.A. Pantaleoni collection.

Further specimens. * 19 July 2017, 1 specimen (very probably female), San Gregorio, Sinnai, SESardinia, 39॰18'19'N 9²2'10'E, about $100 \mathrm{~m}$ from the emergence trap, light trap, photographed but not collected (Fig. 4).

Distribution. W-Mediterranean species known from Morocco (Aspöck U. \& Aspöck H., 1991), Iberian Peninsula (Tillier et al., 2011; Monserrat, 2014), southern France (Mazel, 2004) and Corsica (Letardi et al., 2008). New to Italy.
REMARKS. Isoscelipteron glaserellum is rarely collected. Monserrat (2014), who summarizes the Iberian findings, cites just over 50 specimens, the vast majority of which were collected by means of light trap, one or two (occasionally three) specimens at a time. The captures took place in heterogeneous wooded habitats in Mediterranean environments.

The larval stage is known only for specimens reared from eggs from captive pregnant females (Monserrat, 2014). Therefore its bio-ecology is almost unknown. Larval termitophily and termitophagy is the most accredited hypothesis, but weakly demonstrated. This hypothesis is based on:

i) occasional findings of preimaginal stages of the Nearctic species of the genus Lomamyia Banks, 1904 near termite (particularly Reticulitermes Holmgren, 1913) nests (Gurney, 1947; Johnson \& Hagen, 1981);

ii) exclusive acceptance of termites as prey in both Lomamyia and Isoscelipteron larvae (Tauber \& Tauber, 1968; Brushwein, 1987; Monserrat, 2014), associated with a complex attack behaviour (Johnson \& Hagen, 1981; Komatsu, 2014);

iii) perfect overlap of Isoscelipteron geographic ranges and Reticulitermes geographic ranges at least in the W-Palearctic region (compare maps in Austin et al., 2002, and Aspöck U. \& Randolf, 2014).

The presence of termites in the woodpile can be excluded, whereas the presence under the woodpile can be neither confirmed nor excluded. The woodpile base is partly constituted by a dry stone wall: a termite nest deep in the soil is very unlikely, while the presence of termite tracks is possible. Unfortunately, the information provided by these findings does not help to clarify the biology of I. glaserellum, but rather broadens the hypotheses from which to start.

In any case, positive phototaxis of $I$. glaserellum is very occasional. One of the authors (RR) frequently performed light trapping sessions, often once a week at the site of the emergence trap, without further captures.

Dendroleon pantherinus (Fabricius, 1787)

Neuroptera Myrmeleontidae

EXAMINED MATERIAL. Specimens from emergence trap. * 1 July 2017, 1 specimen, photographed but not collected (Fig. 5). 

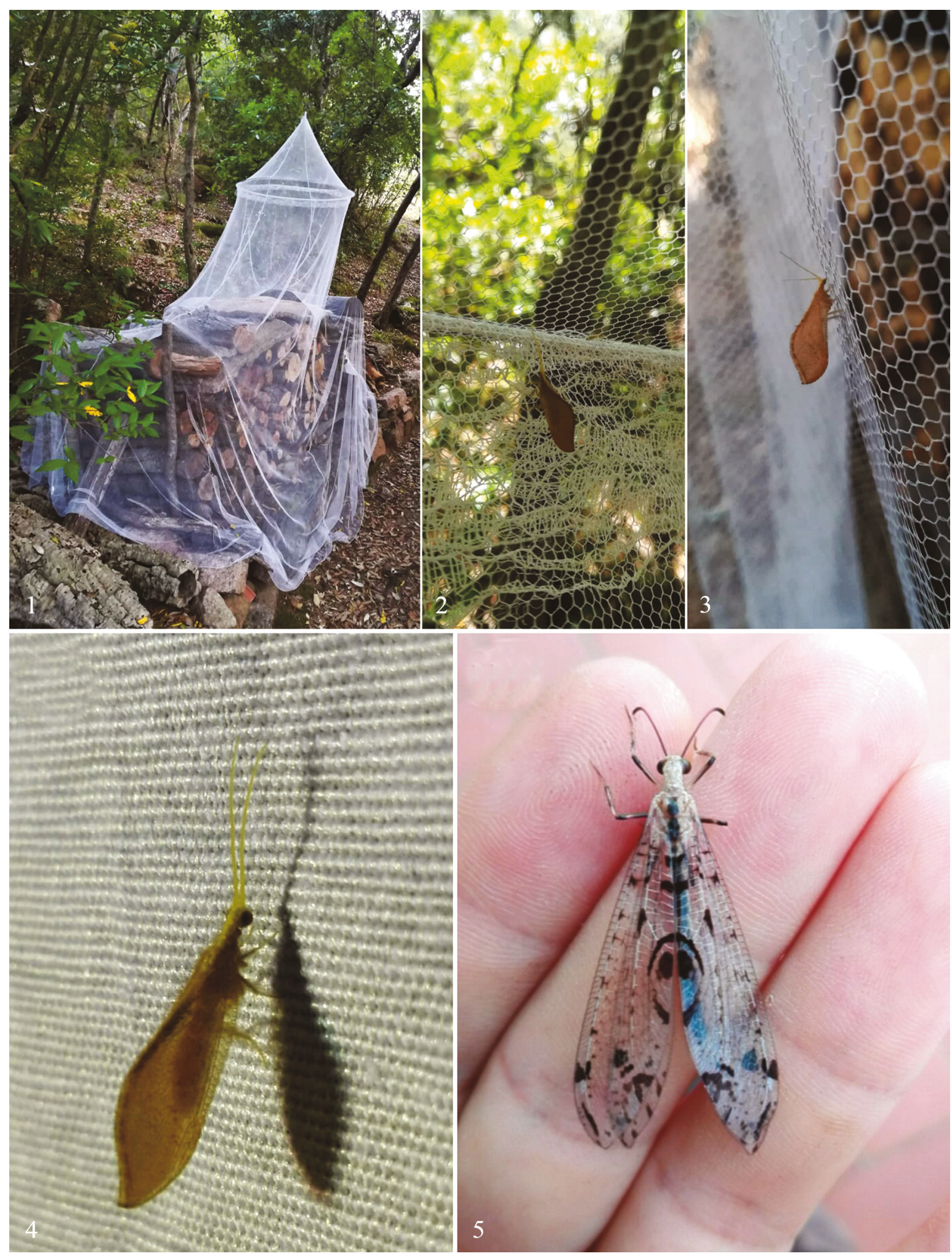

Figure 1. Emergence trap (2020 installation), San Gregorio, Sinnai, SE-Sardinia. Figure 2. Isoscelipteron glaserellum (Neuroptera Berothidae), male specimen in the emergence trap, 22 June 2020. Figure 3. Female specimen resting on the external side of the trap, 21 September 2020. Figure. 4. Specimen attracted by light, 19 July 2017. Figure 5, Dendroleon pantherinus (Neuroptera Myrmeleontidae), specimen found in the trap, 1 July 2017. 
Further specimens. * 20 June 2004, 3 females, Cabras Lagoon [39 $\left.56^{\circ} \mathrm{N} 8^{\circ} 30^{\prime} \mathrm{E}\right]$, Oristano, Sardinia, collector unknown, pinned, R. Nicoli Aldini collection. * 17 July 2014, 1 male, San Gregorio,

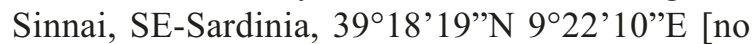
further details known], collected by the late Francesco Rattu, pinned, R. Rattu collection.

Distribution. European distribution, species absent from the Iberian Peninsula but present in the Caucasus (Aspöck H. et al., 2001), further records from Asia refer to closely related species (Krivokhatsky, 2011). In W-Mediterranean, known in France and Corsica (Colombo et al., 2013), and peninsular Italy and Sicily ([Bernardi] Iori et al., 1995). New to Sardinia.

Remarks. Dendroleon pantherinus is widely distributed, although records are often occasional. Almost all captures occur in temperate broadleaved forests, a large percentage inside buildings located in the forests (Colombo et al., 2013). Only occasionally has it been collected in large numbers, i.e. in very favorable habitats (Duelli, pers. comm.; Pantaleoni, unpublished).

The first few collections of the larvae (Brauer, 1867; Roubal, 1936; Kelner-Pillault, 1958) occurred in old hollow trees, specifically in holes filled with dry detritus. Consequently, for many years this was considered its exclusive habitat. Mature broadleaved forests, rich in old trees, appeared to be the preferred habitat of the adults too. However, in a survey of 183 hollow trees $D$. pantherinus was registered in only 11 cases (Colombo et al., 2013).

Steinmann (1967) was the first author to attribute wider ecological range to the larvae of this species. Still, his statement that larvae can live in street dust ('utca porában') was neglected at least until the behavioural synanthropy of this species was demonstrated by Gepp \& Hölzel (1989) and Gepp (2010). The larvae are able to live in house dust, in carpets and other unexpected situations. Exploring an abandoned house (24 July 2010, Campigno, Marradi, Florence, Tuscany, $44^{\circ} 01^{\prime} 28.97^{\prime} \mathrm{N} 11^{\circ} 35^{\prime} 17.77^{\prime} \mathrm{E}$ ) in which an adult of $D$. pantherinus was collected, one of the authors (RAP) found I and II instar exuviae of this species in the ash of a firebox, enriched by bat feces dropping throughout the fuel. This disaggregated material on the hearth hosted many saprophages, such as Dermestidae and Tenebrionidae larvae.
The larvae have also been collected under bark (Tröger, 1999). Two further unpublished reportings of this behavior are available:

i) 26 March 2013, a larva collected under Quercus suber L. bark by Marco Bastianini and Stefano Nappini, Bandite di Scarlino, Grosseto, Tuscany, Italy;

ii) 26 March 2015, a larva collected under oak bark in a mixed (Tilia, Carpinus, Quercus, Fagus, Fraxinus, Ulmus) broadleaved forest by Alexandru Mihai Pintilioaie, near Tomesti, Iasi, Moldova, Romania.

The capture using an emergence trap in Sardinia is probably also due to a mature larva living under the bark of the logs in the woodpile.

The presence of $D$. pantherinus in Sardinia must be wider than suspected. The specimens from Oristano remained for years in the collection of RNA considered as not being fully reliable, due to the unknown collector and the environments near the capture locality. However, the new findings in SE-Sardinia have added evidence supporting the reliability of this old finding.

In conclusion, $D$. pantherinus is preferentially associated with mature broadleaved forests, but is able to adapt to many wooded habitats, from coppices to urban parks (our colleague Maurizio Pavesi found specimens in the attic of the Museo Civico di Storia Naturale in Milan, which is located in an area - 'Giardini Pubblici di Porta Venezia' - characterized by the presence of many trees). The motionless larvae are ambush predators, staying concealed with their bodies covered by debris, in a variety of microhabitats, including anthropogenic ones. The scarcity of this species in collections is probably more due to the adult behavior, such as remaining in the canopy or weak positive phototaxis, than to a true rarity.

\section{ACKNOWLEDGEMENTS}

Grateful thanks to the many colleagues and friends who made their data on Dendroleon pantherinus available to us: Marco Bastianini (Follonica, Italy), Peter Duelli (Birmensdorf, Switzerland), Johannes Gepp (Salzburg, Austria), Stefano Nappini (Castiglione della Pescaia, Italy), Maurizio Pavesi (Milano, Italy), Alexandru Mihai Pintilioaie (Iaşi, Romania), Giovanni Rivalta (Bag- 
nacavallo, Italy). Special thanks are due to Agostino Letardi (Roma, Italy) for his critical reading and to Victor J. Monserrat (La Herradura, Granada, Spain) for interesting discussions on Isoscelipteron.

\section{REFERENCES}

Aspöck H., Hölzel H. \& Aspöck U., 2001. Kommentierter Katalog der Neuropterida (Insecta: Raphidioptera, Megaloptera, Neuroptera) der Westpaläarktis. Denisia, 2: 1-606.

Aspöck U. \& Aspöck H., 1991. Zur Kenntnis des Genus Isoscelipteron Costa, 1863 (Neuropteroidea: Neuroptera: Berothidae: Berothinae). Zeitschrift der Arbeitsgemeinschaft Österreichischer Entomologen, 43: 65-76.

Aspöck U. \& Randolf S., 2014. Beaded lacewings - a pictorial identification key to the genera, their biogeographics and a phylogentic analysis (Insecta: Neuroptera: Berothidae). Deutsche Entomologische Zeitschrift, (N.F.)61: 155-172. https://doi.org/10. 3897/dez.61.8850

Austin J., Szalanski A., Uva P., Bagnères A.-G. \& Kence A., 2002. A comparative genetic analysis of the subterranean termite genus Reticulitermes (Isoptera: Rhinotermitidae). Annals of the Entomological Society of America, 95: 753-760. https://doi.org/10.1603/ 0013-8746(2002)095[0753:ACGAOT]2.0.CO;2

[Bernardi] Iori A., Kathirithamby J., Letardi A., Pantaleoni R.A. \& Principi M.M., 1995. 62. Neuropteroidea (Megaloptera, Raphidioptera, Planipennia), Mecoptera, Siphonaptera, Strepsiptera. In: Minelli A., Ruffo S. \& La Posta S. (Eds.), Checklist delle specie della fauna italiana. Calderini Editore, Bologna, $20 \mathrm{pp}$.

Brauer F., 1867. Beschreibung und Verwandlung des Dendroleon pantherinus Fbr. und Vergleich der bis jetzt bekannten Myrmeleoniden- und AscalaphidenLarven. Verhandlungen der Kaiserlich-Königlichen Zoologisch-Botanischen Gesellschaft in Wien, 17: 963-966.

Brushwein J.R., 1987. Bionomics of Lomamyia hamata (Neuroptera: Berothidae). Annals of the Entomological Society of America, 80: 671-679. https://doi. org/10.1093/aesa/80.5.671

Colombo R., Braud Y. \& Danflous S., 2013. Contribution à la connaissance de Dendroleon pantherinus (Fabricius 1787) (Neuroptera: Myrmeleontidae). Revue de 1'Association Roussillonnaise d'Entomologie, 22: 47-53.

Duelli P., Moretti M., Tonolla D. \& Barbalat S., 2006. Scented traps yield two large lacewing species (Neuroptera, Chrysopidae) new to Switzerland. Mitteilun- gen der Schweizerischen Entomologischen Gesellschaft, 79: 25-28.

Gaston K.J., 1994. Rarity. Springer Netherlands, X+205 pp. https://doi.org/10.1007/978-94-011-0701-3

Gepp J., 2010. Ameisenlöwen und Ameisenjungfern. Myrmeleontidae. Eine weltweite Betrachtung unter besonderer Berücksichtigung Mitteleuropas. 3., neubearbeitete Auflage. Die Neue Brehm-Bücherei 589. Westarp Wissenschaften-Verlagsgesellschaft, Hohenwarsleben, Germany, 168 pp.

Gepp J. \& Hölzel H., 1989. Ameisenlöwen und Ameisenjungfern. Myrmeleonidae. Die Neue Brehm-Bücherei 589. A. Ziemsen Verlag, Wittenberg Lutherstadt, 108 pp.

Ghilarov M.S., 1962. The larva of Dilar turcicus Hag. and the position of the family Dilaridae in the order Planipennia. Entomological Review, 41: 402-416. [in Russian, original $=$ Гиляров М. С., 1962. Личинка Dilar turcicus Hag. и положение семейства Dilaridae в отряде сетчатокрылых (Planipennia). Энтомологическое Обозрение.]

Gurney A.B., 1947. Notes on Dilaridae and Berothidae, with special reference to the immature stages of the Nearctic genera (Neuroptera). Psyche, 54: 145-169.

Johnson J.B. \& Hagen K.S., 1981. A neuropterous larva uses an allomone to attack termites. Nature, 289: 506-507. https://doi.org/10.1038/289506a0

Kelner-Pillault S., 1958. Le microclimat des terreaux d'arbres creux et son influence sur le peuplement entomologique. Bulletin de la Société Entomologique de France, 63: 207-213.

Komatsu T., 2014. Larvae of the Japanese termitophilous predator Isoscelipteron okamotonis (Neuroptera, Berothidae) use their mandibles and silk web to prey on termites. Insectes Sociaux, 61: 203-205. https:// doi.org/10.1007/s00040-014-0346-6

Krivokhatsky V.A., 2011. Antlions (Neuroptera: Myrmeleontidae) of Russia. KMK, Saint Petersburg, Russia, 334 pp. [in Russian, original = Кривохатский В.А., 2011. Муравьиные львы (Neuroptera: Myrmeleontidae) России. Товарищество Научных Изданий КМК, Санкт-Петербург, 334 pp.]

Letardi A., Thierry D., Tillier P. \& Canard M., 2008. Mise à jour de la faune des Neuropterida de Corse (Raphidioptera \& Neuroptera). Revue de l'Association Roussillonnaise d'Entomologie, 17: 95-105.

Mazel R., 2004. Questions paléobiogéographiques posées par la découverte en France de Berotha glaserella Aspöck et Aspöck et Hölzel, 1979 (Neuroptera, Planipennia, Berothidae). Revue de l'Association Roussillonnaise d'Entomologie, 13: 15-17.

Monserrat V.J., 2014. Los berótidos de la Península Ibérica (Insecta: Neuropterida: Neuroptera: Berothidae). Heteropterus Revista de Entomología, 14: 31-54. 
Owen J.A., 1989. An emergence trap for insects breeding in dead wood. British Journal of Entomology and Natural History, 2: 65-67.

Owen J.A., 1992. Experience with an emergence trap for insects breeding in dead wood. British Journal of Entomology and Natural History, 5: 17-20.

Roubal J., 1936. Dendroleon pantherinus F. Casopis Ceskoslovenské Spolecnosti Entomologické [=Acta Societatis Entomologicae Cechosloveniae], 33: 172173.

Steinmann H., 1967. Tevenyakú fátyolkák, Vízifátyolkák, Recésszárnyúak és Csőrös rovarok - Raphidioptera, Megaloptera, Neuroptera és Mecoptera. Fauna Hungariae, 82: 204+3.
Tauber C.A. \& Tauber M.J., 1968. Lomamyia latipennis (Neuroptera, Berothidae) life history and larval descriptions. Canadian Entomologist, 100: 623-629. https://doi. org/10.4039/Ent100623-6

Tillier P., Mota Almeida J. \& Cloupeau R., 2011. Isoscelipteron glaserellum (U. Aspöck, H. Aspöck \& Hölzel, 1979), espèce nouvelle pour la fauna du Portugal (Neuroptera, Berothidae). Bulletin de la Société Entomologique de France, 116: 283-284.

Tröger E.J., 1999. Eine neuentdeckte Population von Dendroleon pantherinus F. (Neuroptera: Myrmeleontidae) am Schwarzwaldrand. Galathea, Berichte des Kreises Nürnberger Entomologen e. V., Supplement 5: 5-7. 